\title{
A Practical Laboratory Study Simulating the Percutaneous Lumbar Transforaminal Epidural Injection: Training Model in Fresh Cadaveric Sheep Spine
}

\author{
Perkütan Lomber Transforaminal Epidural Enjeksiyonu Taklit Eden \\ Pratik Laboratuvar Çalışması: Taze Kadavratik Koyun Omurgasında \\ Eğitim Modeli
}

\author{
Husnu SUSLU \\ Dr. Lutfi Kirdar Kartal Education and Research Hospital, Department of Algology, Istanbul, Turkey
}

Correspondence address: Husnu SUSLU / E-mail: husnususlu@yahoo.com

\begin{abstract}
AIM: Laboratory training models are essential for developing and refining treatment skills before the clinical application of surgical and invasive procedures. A simple simulation model is needed for young trainees to learn how to handle instruments, and to perform safe lumbar transforaminal epidural injections. Our aim is to present a model of a fresh cadaveric sheep lumbar spine that simulates the lumbar transforaminal epidural injection.

MATERIAL and METHODS: The material consists of a 2-year-old fresh cadaveric sheep spine. A 4-step approach was designed for lumbar transforaminal epidural injection under C-arm scopy.

RESULTS: For the lumbar transforaminal epidural injection, the fluoroscope was adjusted to get a proper oblique view while the material was stabilized in a prone position. The procedure then begin, using the C-arm guidance scopy.

CONCLUSION: The model simulates well the steps of standard lumbar transforaminal epidural injections in the human spine. The cadaveric sheep spine represents a good method for training and it simulates fluoroscopic lumbar transforaminal epidural steroid injection procedures performed in the human spine.
\end{abstract}

KEYWORDS: Cadaver dissection, Lumbar spine, Sheep spine, Transforaminal, Training model

öz

AMAÇ: Laboratuvar eğitim modelleri cerrahi ve invaziv prosedürlerin klinik uygulamasından önce tedavi becerilerini geliştirmek ve rafine etmek için gereklidir. Araçların nasıl işleneceğini öğrenmek ve güvenli lomber transforaminal epidural enjeksiyonları gerçekleştirmek için basit bir simülasyon modeli genç stajyerler için gerekir. Amacımız, transforaminal lomber epidural enjeksiyonu taklit eden kadavratik taze koyun lomber omurga modeli sunmaktır.

YÖNTEM ve GEREÇLER: Malzeme 2-yaşında taze bir kadavratik koyun omurgasından sağlandı. C- kollu skopi altında lomber transforaminal epidural enjeksiyon 4 basamakta tasarlandı.

BULGULAR: Lomber transforaminal epidural enjeksiyon için fluoroskopi, materyal prone pozisyonda sabitlenmiş iken tamamıyla eğimli bir görüntü almak için ayarlandı. Prosedüre C-kollu skopi kullanılarak başlandı.

SONUÇ: Modelde insan omurgasındaki standart lomber transforaminal epidural enjeksiyonun basamakları iyi stimüle edilir. Kadavratik koyun omurgası eğitim için iyi bir metodu temsil eder ve insan omurgasında yapılan lomber transforaminal epidural steroid enjekte etme prosedürlerinin taklit eder.

ANAHTAR SÖZCÜKLER: Kadavra diseksiyonu, Lomber vertebra, Koyun vertebrası, Transforaminal enjeksiyon, Eğitim modeli 


\section{INTRODUCTION}

With fluoroscopically guided spinal injections becoming more common, precise access to the intervertebral foramen, as well as the pain generators, is possible through a safe and reliable technique $(3,12,15)$. Transforaminal epidural steroid injections under mobile $\mathrm{C}$-arm guidance is an effective nonsurgical treatment option for patients with degenerative lumbar scoliotic stenosis and radiculopathy. These injections are commonly used to deliver medication selectively to the epidural space near the exiting spinal nerves. The goal of the transforaminal approach is to enter the intervertebral foramen, while avoiding dural puncture, vascular injection, and segmental nerve trauma $(1,9,10)$. Epidural anatomy and pathologic conditions will affect the spread of an injectate, further complicated by the presence of induration, mass effect, or scar. These risks are well managed if meticulous technique and due diligence are practiced by well-trained physicians.

Training in the laboratory to gain familiarity with the techniques of pain treatment and to acquire skills in handling instruments is fundamental $(2,4,5,6,7,8,12,14)$. Practicing pain treatment skills and gaining experience on animal or cadaveric models before exposure to patients are useful.

\section{MATERIALS and METHODS}

This study was performed at the Dr. Lutfi Kırdar Kartal Education and Research Hospital. The sheep spine was obtained from a local butcher. The material consisted of a 2-year-old fresh cadaveric sheep spine (thoracal and lumbar region). It was kept in the refrigerator at $4-8^{\circ} \mathrm{C}$ for 6 hours after the specimen was obtained. The specimen was placed prone on the $\mathrm{x}$-ray table top which was padded to provide flattening of the lumbar lordosis and stabilized. The positioning of the sheep spine is in the similar prone position. A 22-gauge spinal needle was used. Two ml of non-ionic contrast (Omnipaque 300) was used for injection. The procedure was performed under $\mathrm{C}$-arm guidance (Ziehm 8000, Ziehm imaging GmbH, Germany). The steps were adjusted to get the proper oblique view for showing the biggest neural foramen.

\section{RESULTS}

For the lumbar transforaminal epidural injection, the fluoroscope was adjusted to get a proper oblique view while the material was in a prone position and stabilized. The procedure then begin, using the C-arm guidance scopy.

The first step consists of the lumbar pedicle corresponding to the targeted foramen (Figure 1). The lumbar region is prepared with a 22-gauge spinal needle using an anterioposterior (AP) view and oblique view image. To obtain the best oblique view of the lumbar intervertebral foramen, a true AP view was made first and the scope was rotated toward the side to be injected approximately $30^{\circ}$. Oblique view with a 22-gauge spinal needle in excellent position and in the middle aspect of the foramen.

The second step consists of a 22-gauge spinal needle percutaneously advanced through the tissues toward the target (Figure 1). Spot AP and oblique fluoroscopic images were used throughout the spinal needle insertion while the spinal needle is advanced in small increments. An appropriate length styleted 22-gauge needle was guided inferior to the pars interarticularis and into the neural foramen.

The third step consists of verification of final needle position by C-arm scopy in the AP and oblique view (Figure 1). The spinal needle tip is positioned just caudal to the pedicle shadow under the 6 o'clock position. Note needle tip is in excellent position just lateral to the "6:00" position under the lumbar pedicle.

The fourth step consists of non-ionic contrast material injected (Figure 1). In the AP view of the lumbar spine, the final position of the needle is demonstrated for lumbar transforaminal injection. Two ml of non-ionic contrast material (Omnipaque 300) is injected to document the appropriate contrast spread along the spinal nerve into the epidural space. 2 minute was enough for the contrast to dissipate at spine. Three-dimensional reconstruction of fire-slice CT data showing post-contrast image of sheep spine with needle after one hour (Figure 2).

\section{DISCUSSION}

Percutaneous lumbar transforaminal epidural steroid injections are used for the treatment of lower back pain with a radicular component secondary to lumbar disc pathology or failed back surgery syndrome. Transforaminal epidural injections of anesthetic and corticosteroids are generally safe with a reported minor complication rate of $10 \%$ in the lumbar spine $(3,17)$. Advantages of transforaminal corticosteroid injection come with increased complexity, requiring technical expertise, and bringing with it a significantly increased risk of morbidity. Rare but serious morbidity has also been documented including intravascular injection, dural puncture, transient paraplegia, spinal cord infarction with myelopathy, subdural hematoma, cerebellar infarct, and death $(1,15)$. Potential complications of dural puncture and subsequent injection into the subdural and subarachnoid spaces include cauda equina and conus medullaris syndromes, persistent paresthesias, arachnoiditis, meningitis, temporary respiratory depression, ascending weakness/sensory loss, apnea, and unconsciousness $(9,10,11,15)$. Recognition of abnormal contrast flow during transforaminal epidural injection should help reduce the risk of these complications. These cases demonstrate appropriately placed needles, yet upon injection of contrast, subdural disbursement of contrast ensued. The purpose of these cases is to demonstrate contrast patterns that occur after dural puncture, which can occur despite apparent proper needle placement and lack of CSF flashback.

The anatomy of the lumbar intervertebral foramen is complex. Therefore, a good knowledge of the anatomy, and appropriate handling of the needle is essential. A pair of spinal nerve roots leaves and penetrates the dural sac in an inferolateral direction, taking with them an extension of dura and arachnoid mater referred to as the dural sleeve $(12,14)$. 

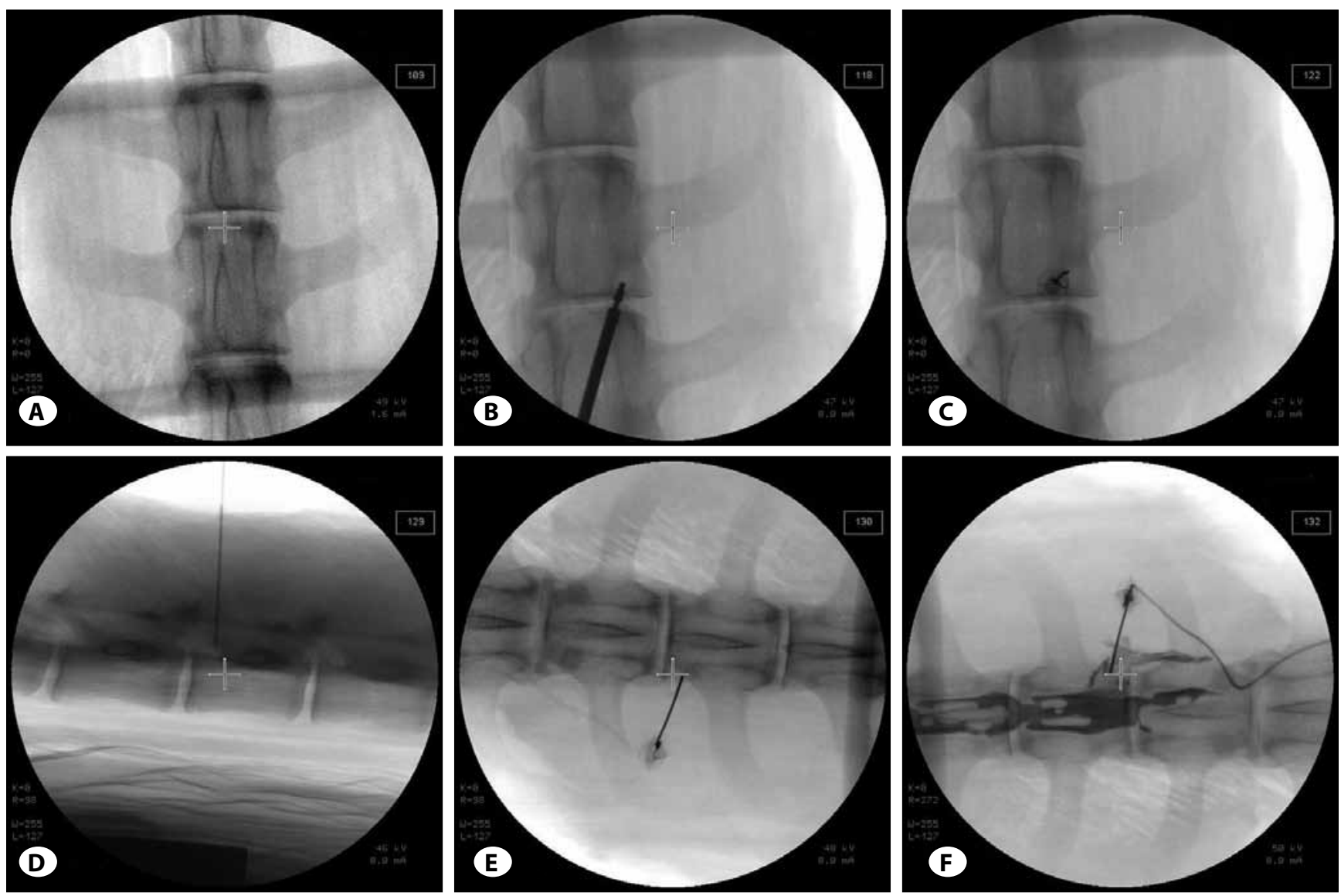

Figure 1: The step of lumbar transforaminal epidural injection. A) By C-arm scopy in the AP view. B) The C-arm is then rotated until an ipsilateral oblique view projects the superior articular process of the intrasegmental level so that it appears to lie under the 6 o'clock position of the target pedicle. C) The needle was placed in the superior and anterior aspect of the corresponding neuroforamen under fluoroscopy in oblique view. D) Needle was showed laterally view. E) Verification of final needle position by fluoroscopy in AP view is mandatory at this stage of the procedure. F) Post-contrast image of sheep spine with needle was demonstrated by AP view.
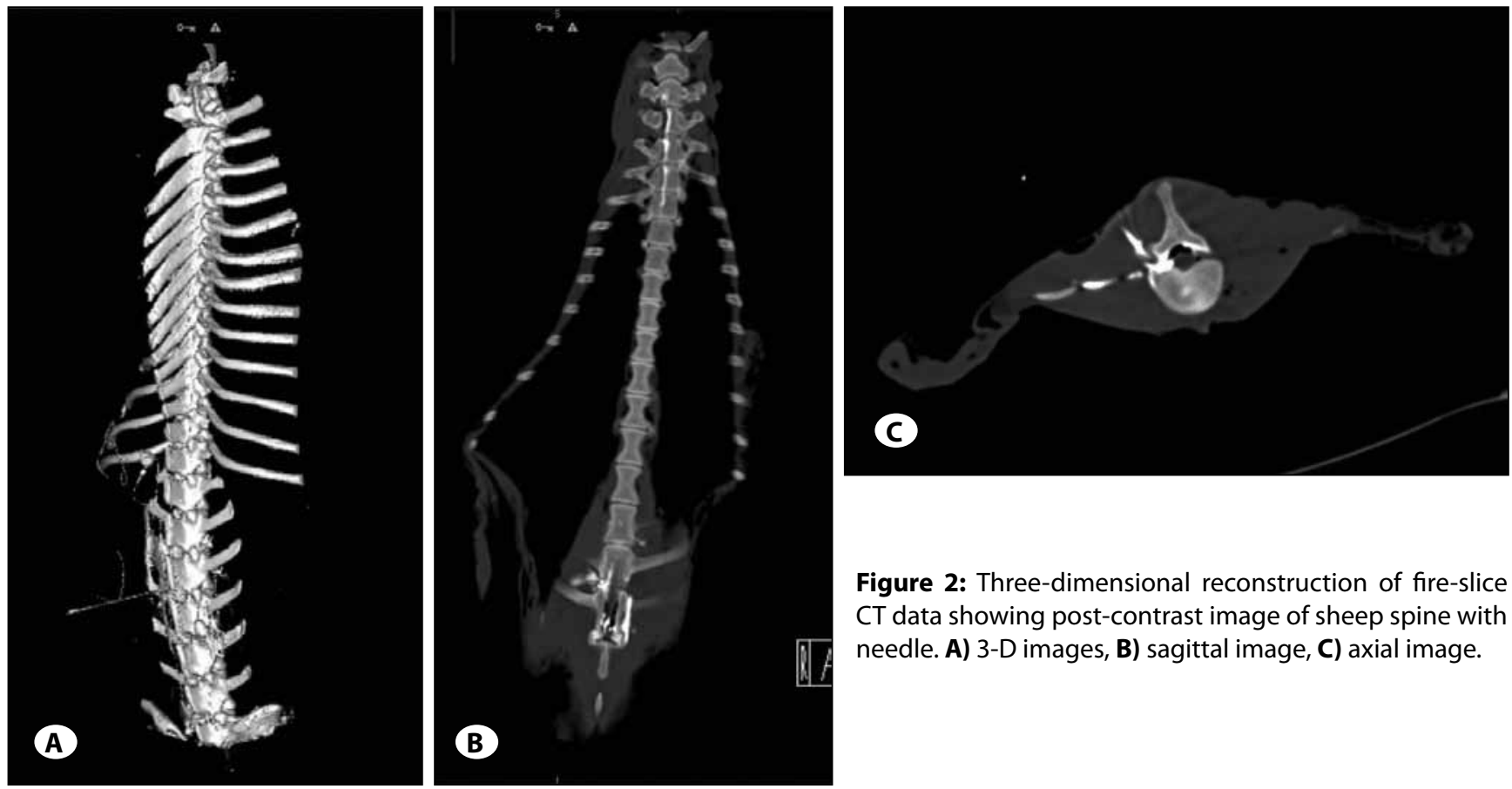

Figure 2: Three-dimensional reconstruction of fire-slice CT data showing post-contrast image of sheep spine with needle. A) 3-D images, B) sagittal image, C) axial image. 
The optimal target point for transforaminal epidural steroid injections lies on the posterior surface of the vertebral body, adjacent to the caudal border of the pedicle above the target nerve, opposite the sagittal bisector of the pedicle. When viewed under scopy, this point also described as the 6 o'clock position lies in the upper margin of the traditionally described "safe triangle" $(12,17)$. A needle may be introduced into the upper and lateral reaches of the triangle and adjusted to the point, if necessary, with less risk of puncturing the dural sleeve of the target nerve. The 6 o'clock position is used because the dural sleeve typically ends medial to this position $(12,17)$. When properly performed, transforaminal injections should result in ventrolateral contrast spread along the segmental nerve. The target is the segmental nerve and dorsal root ganglion within the radicular canal. We, thus, believe that training on models is necessary before procedures in the patient.

Animal models have been commonly used for in vivo and in vitro spinal research. The animals selected for spine in vivo research must be of an appropriate size both at the beginning and at the end of the experiment. Sheep spine may be a useful model for experiments related to the gross structure of the spine (18). Sheep spines are easily available and provide an alternative to human cadavers $(5,8,14)$. The practice on cadaveric sheep spines described here has several advantages: the material is cheap, convenient to manage, and easy to obtain, and neither a specific facility for maintaining living animals nor anesthesia is required. The preparation of model is very simple. Regarding the regional differences sheep is more convenient and easier too find our country. The use of cadaveric sheep spine raises no ethical considerations. The specimen should be provided from a known source and from animals under veterinary control. We also recommend that instruments used in the study should not be used in human subjects, and all sterilization measures should be absolutely rigorous. Cleaning instruments and table tops with sodium hypochlorite (2-hour exposure to 20,000 ppm chlorine) may be advisable.

Height is greater in the sheep spine than in the human spine in the thoracic and lumbar regions, but the width and depth are less (18). Another difference is the curvature in the lumbar spine, which for the sheep is slightly kyphotic rather than lordotic (16). The lower transition to a decreasing pedicle height, which occurs at T11-T12 in the human spine, does not occur until L5 in the sheep spine. Thus, the differences again become exaggerated in the lumbar spine, with pedicle and vertebra height actually being more closely correlated in the sheep than in the human spine $(16,18)$. The spinal canal width are nearly identical, although they differ in value, again mostly toward the extremes. The sheep and human spinous process in the lumbar region is about the same length. The tip-to-tip transverse process width is very similar between in the cervical and thoracic regions but diverges somewhat in the lumbar spine $(16,18)$. Facet height and width mostly overlap between the sheep and human, except for width in the thoracic region, which is considerably less in sheep $(16,18)$.

The cadaveric sheep spine model presented here is intended only for laboratory training, as discussed previously. This is not an anatomic study of the sheep spine in the context of veterinary medicine (13). Therefore, except for the anatomic similarities to corresponding structures of the human spine, other definitions, locations, and variations of vessels and neural structures mentioned in this article are not the subject of the training model and are beyond the scope of this study.

\section{CONCLUSION}

We believe that laboratory training is an important step for training in invasive pain procedures. This model of cadaveric sheep spine does simulate well the standard steps of the percutaneous transforaminal epidural injection to the lumbar spine, and is a useful method for accustoming pain trainees and residents to transforaminal procedures performed on the human spine.

\section{REFERENCES}

1. Bolwin KP, Gruber RD, Bouchlas CG, Torres-Ramos FM, Freeman TL, Slaten WK: Complications of fluoroscopically guided transforaminal lumbar epidural injections. Arch Phys Med Rehabil 81:1045-1050,2000

2. Dawley JD, Moeller-Bertram T, Wallace MS, Patel PM: Intraarterial injection in the rat brain: Evaluation of steroids used for transforaminal epidurals. Spine (Phila Pa 1976) 34: 1638-1643, 2009

3. Furman MB, O'Brien EM, Zgleszewski TM: Incidence of intravascular penetration in transforaminal lumbosacral epidural steorid injections. Spine 25:2628-2632, 2000

4. Galeano M, Zarabini AG: The usefulness of a fresh chicken leg as an experimental model during the intermediate stages of microsurgical training. Ann Plast Surg 47:96-97, 2001

5. Hamamcioglu MK, Hicdonmez T, Tiryaki M, Cobanoglu S: A laboratory training model in fresh cadaveric sheep brain for microneurosurgical dissection of cranial nerves in posterior fossa. British Journal of Neurosurgery 22: 769-771, 2008

6. Hicdonmez T, Hamamcioglu MK, Parsak T, Cukur Z, Cobanoglu S: A laboratory training model for interhemispherictranscallosal approach to the lateral ventricle. Neurosurg Rev 29:159-162, 2006

7. Hicdonmez T, Hamamcioglu MK, Tiryaki M, Cukur Z, Cobanoglu S: Microneurosurgical training model in fresh cadaveric cow brain: A laboratory study simulating the approach to the circle of Willis. Surgical Neurology 66: 100-104, 2006

8. Hicdonmez T, Parsak T, Cobanoglu S: Simulation of surgery for craniosynostosis: A training model in a fresh cadaveric sheep cranium. J Neurosurg (2 Suppl Pediatrics) 105:150-152, 2006

9. Houten JK, Errico TJ: Paraplegia after lumbosacral nerve root block: Report of three cases. Spine J 2:70-75, 2002 
10. Huntoon MA: Anatomy of the cervical intervertebral foramina: Vulnerable arteries and ischemic neurologic injuries after transforaminal epidural injections. Pain 117:104-111, 2005

11. Kennedy DJ, Dreyluss P, April CN, Bogduk N: Paraplegia following image-guided transforaminal lumbar spine epidural steroid injection: Two case reports. Pain Med 10:1389-1394, 2009

12. Manchikanti L, Singh V, Kloth D, Slipman CW, Jasper JF, Trescot AM, Varley KG, Atluri SL, Giron C, Curran MJ, Rivera J, Baha AG, Bakhit CE, Reuter MW: Interventional techniques in the management of chronic pain: Part 2.0. Pain Physician 4: 24-96, 2001

13. Popesko P: Atlas der topographischen Anatomie der Haustiere. Band I: Kopf und Hals. Stuttgart: Ferdinand Enke Verlag, 1989:44-45
14. Reid JE, Maekin JR, Robins SP: Sheep lumbar intervertebral discs as model for human disc. Clin Biomech 17:312 -314, 2002

15. Schaufele MK, Hatch L, Jones W: Interlaminar versus transforaminal epidural injections for the treatment of symptomatic lumbar intervertebral disc herniations. Pain Physician 9 :361-366, 2006

16. Sheng SR, Wang XY, Xu HZ, Zhu GQ, Zhou YF: Anatomy of large animal spines and its comparison to the human spine: $A$ systematic review. Eur Spine J. 19:46-56, 2010

17. Valat JP, Giraudeau B, Rozenberg $S$, Goupille $P$, Bourgeois $P$, Micheau-Beaugendre V, Soubrier M, Richard S, Thomas E: Epidural corticosteroid injections for sciatica: A randomised, double blind, controlled clinical trial. Ann Rheum Dis 62: 639-643, 2003

18. Wilke HJ, Kettler A, Wenger KH, Claes LE: Anatomy of the sheep spine and its comparison to the human spine. Anat Rec 247:542-555, 1997 